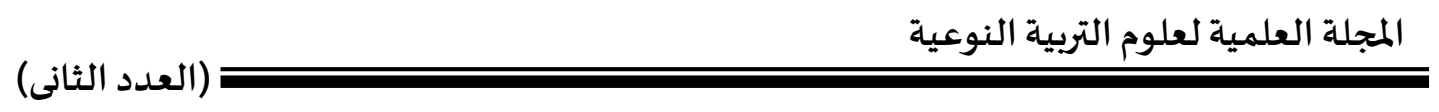

\title{
EFFECT OF POMEGRANATE PEEL ON THE BLOOD GLUCOSE LEVEL OF EXPERIMENTAL RATS
}

\author{
** Magda Ramzy, *Wafai Z.A. Mikhail, * Hassan M. Sobhy, ** Sahar A. \\ Khairy, ${ }^{* *}$ Ola Ail Ail \\ * Institute of African Research and Studies Cairo University** National \\ Nutrition Institute, Cairo Egypt
}

\begin{abstract}
The present study investigated the effects of peel of pomegranate peel (Punic granatum $L$ ) on the blood glucose level, some physiological parameters as liver function, kidney function and histological properties of pancreas in diabetic rats.
\end{abstract}

Rats were divided into 2 groups, the first group negative group, and the second group diabetic group which was divided into 4 group's positive control, and 3 diabetic groups fed on several diets $(5 \%, 10 \%, 15 \%)$ of peel for 28 days. Peel was cleaned from impurities and washed with tap water. Drying in Oven air dryer at $45{ }^{\circ} \mathrm{C}$ for 48 hours to dry the peel and was ground in a MultiMill apparatus and passed through a 50 mesh sieve to obtain a fine peel powder. Bodyweight gain, feed intake and food efficiency ratio were calculated at the end of experiment. Fasting blood sample were taken on day 28 for the determination of glucose level, serum urea, aspartate aminotransferase (AST) and glutamic pyruvic transaminase (ALT). The pancreases of all animals were carefully removed and slices from them were fixed in $85 \%$ alcohol for 24 hours, and then processed for paraffin embedding. Histological sections, 7 micron-thick, were cut and stained with heamatoxylin and eosin. They were then microscopically examined to evaluate the effects of the three differant concentration of formalin on these organs.

From the obtained resuits, treatment using pomegranate peel (Punic granatum $L$ ), reduced significantly glucose level in diabetic rats fed different levels of pomegranate peel and the decrease in blood glucose was proportionate with the increase in the level of the supplementation. 
(العدد الثانى)

تاثير قشتور الرمان علي مستوي السكر لفئران التجارب

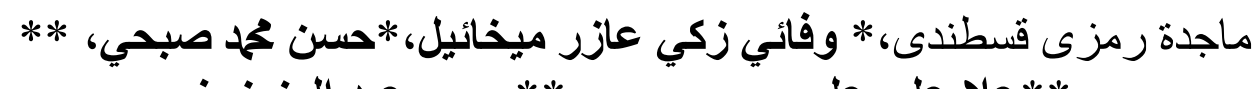

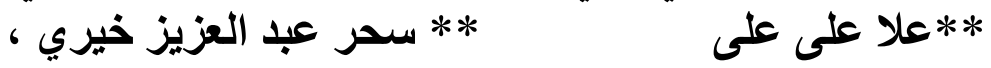

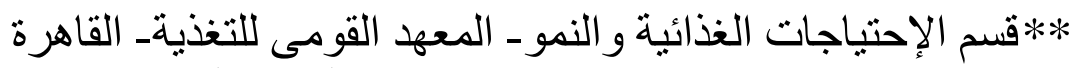

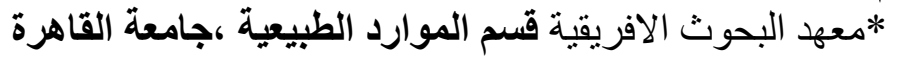

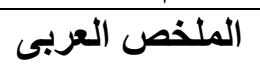

يهذف هذا البحث إلى إمكانية إستخدام بعض مخلفات الثمار مثل قثور الرمان لاعداد وجبات غنية

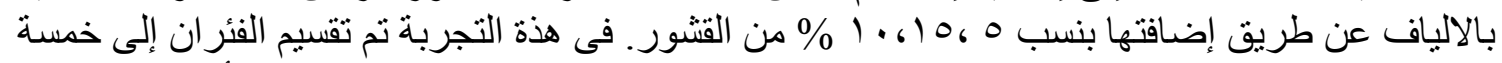

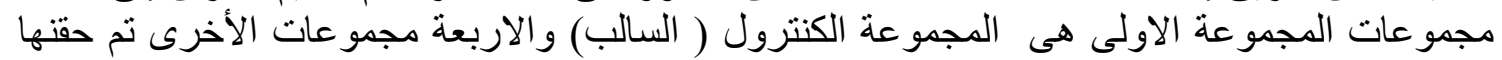

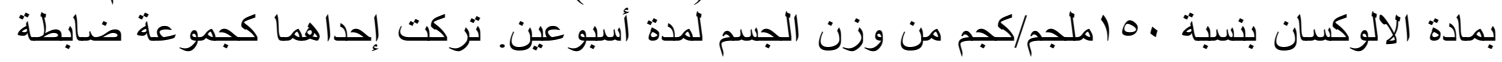

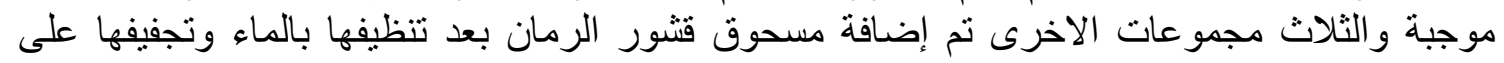

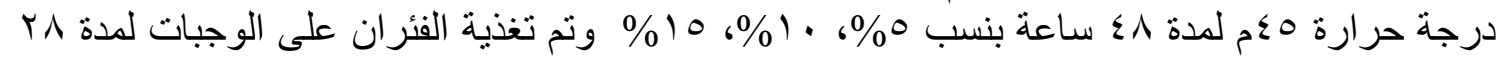

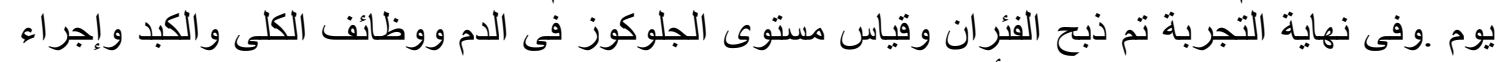

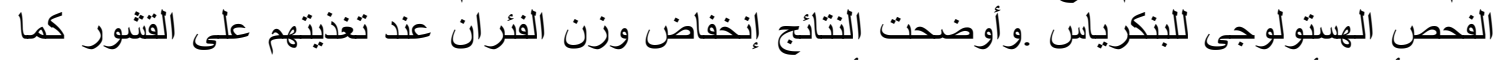

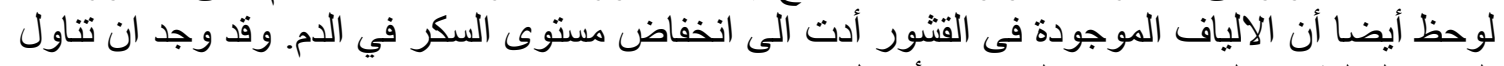

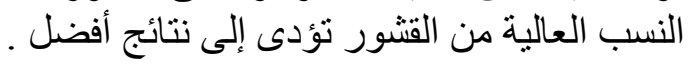

الكلمات الكاثفة :-

قتثور الرمان - الكمانة السكر - وظائف الكبد - وظائف الكلى 


\section{INTRODUCTION}

The pomegranate is an attractive shrub or small tree growing 6 to $10 \mathrm{~m} \mathrm{high}$, the pomegranate fruit has valuable compounds in different parts of the fruit. These can be divided into several anatomical origins: peel, seeds and arils. Another important product obtained from pomegranate fruit is the juice that can be obtained from arils or from whole fruit.(Prakash and Prakash, 2011).

Diabetes mellitus" is used to describe a group of conditions characterized by raised blood glucose levels (hyperglycemia) and a relative or absolute deficiency in insulin (Lawrence et al $\mathbf{2 0 0 5}$ ).

This study aimed to evaluate the effect of pomegranate peel on the blood glucose level, some physiological parameters as liver function, kidney function, and histological properties of pancreas in diabetic rats.

\section{MATERIALS AND METHOD: MATERIAL:}

Pomegranate (punica granatum $L$ ) was obtained from local market. Peel was cleaned from impurities and washed with tap water. Drying Oven in air dryer at $45^{\circ} \mathrm{C}$ was used for 48 hours to dry, then we was ground it in a Multi Mill apparatus and passed through a $0.5-\mathrm{mm}$ mesh sieve to obtain a fine peel powder.

Rats :- fifty four adult male albino rats, Sprague dawley strain, mean weight was $200 \pm 10 \mathrm{~g}$ were obtained from Research Institute of Ophthalmology Medical Analysis Department, Giza, Egypt. The animals were divided into five groups and housed individually in stainless steel cages fitted with a wire mesh bottoms and front in room maintained at $25-30^{\circ} \mathrm{C}$ with about $50 \%$ relative humidity. The room was lighted daily photoperiod of $12 \mathrm{~h}$ light and $12 \mathrm{~h}$ dark. During the conditioning period and throughout the trial food and tap water were provided adlibitum.

Methods: - Rats were divided into 2 groups and were housed individually in the wire cage.All groups of rats were fed on the experimental diets for 28 days according to the following First group was a negative control. Second group was diabetic group. Diabetes was induced in normal healthy adult male rats by intraperitoneal injection of alloxan $150 \mathrm{mg} \backslash \mathrm{kg}$ body weight according to the method described by Desai and Bhide, (1985). Six hours after the injection of alloxan, fasting blood samples were obtained by retro-orbital method to estimate fasting serum glucose. Rats having fasting serum glucose more than $200 \mathrm{mg} \backslash \mathrm{dl}$ were considered diabetics NDDG (1994).

The second group (diabetic rats): were subdivided into 4 groups 6 , rats in each group as follows:

Positive Control (G2): Fed basal diet as (Diabetic control). G3: Fed on basal diet $+5 \%$ pomegranate peel instead of starch.

Group G4: Fed on basal diet $+10 \%$ pomegranate peel instead of starch. GroupG5: Fed on basal diet $+15 \%$ pomegranate peel instead of starch.

Diet: the basal diet was prepared according to AIN (1993). The vitamin mixture and the salt mixture were prepared according to AIN(1977). 
The organ weight was taken on the day of sacrifice (final). The testicles were separated through dissection after trimming off the attached tissues and weighed using volume displacement method.

\section{Biochemical analysis Blood:}

At the start of the experimental period the animals were fasted for $12 \mathrm{~h}$. Weekly blood samples was taken from retro orbit. Blood samples were collected in a clean dry centrifuge tube from hepatic vein and try these in 1 week and in 2 week of experimental period.

At the end of the 4 weeks experimental period the animals were fasted for $12 \mathrm{~h}$. They were anesthetized with diethyl ether. Incisions were made into the abdomen and blood was drawn from hepatic vein. Blood sample was taken on EDTA as whole blood sample for determination blood petsher. Blood samples were immediately collected in dry clean tubes form the portal vein and left to clot at room temperature. Another part tube without anticosulant for separation of serum by centrifugation at 4000 R.P.M. for 10 minutes. The collected samples were analyzed for the following Biochemical parameters. Using serum glucose according to Kaplan (1984) and Trinder (1969), phospholipids Zolliner and Eberhagal, (1965), free fatty acids Falholt et al., (1973) and total Lipids of liver the method which was used according to Bligh and Dyer (1959). Creatinine was determined according to the method described by Bohmer (1971). Urea was determined according to the method described by Patton and Crouch (1977). Aspartate aminotransferase (AST) and Alkaline phosphate (ALT) activities were measured according to method described by Reitman and Frankel (1957).

Histological study: All animals were sacrificed under anahtesia on the $4^{\text {th }}$ week of experiment. The pancreas and of all animals were dissected removed and fixed in $10 \%$ formalin solution. The fixed specimens were then trimmed, washed and dehydrated in ascending grades of alcohol. These specimens were cleared in xylene, embedded in paraffin, sectioned at $4-6$ microns thickness and stained with Hematoxylen and Eosin (H\&E ) then examined microscopically according to Carle'ton (1979).

Statistical analysis: Statistical analysis was carried out according to Snedecor and Cochran (1972), as the mean \pm standard deviation (SD). Statistical analyses was preformed wit statistical package for social science for windows (spss, version 11.0, Chicago, DL-USA).The data were analyses by one- way analyses of variance (ANOVA). To compar the difference between groups, post hoc listing was performed by L.S.D test.

\section{RESULTS AND DISCUSSION}

Effects of feeding different levels of pomegranate peel on feed intake, feed efficiency ratio (FER) and body weight gain (BWG) in diabetic rats are shown in Table(1). FI increased in G5 (15\% peel) when compared with the other groups. On the other hand FER in all diabetic groups increased when compared with the positive group especially G3 (5\% peel). BWG showed a gradual decrease as the level of supplement increased. These results are in accordance with those of Chau ChiFai et al., (2003). 
Data illustrated In Table (2) show effect of feeding different levels of pomegranate peel on relative weight of the organs of alloxan-induced diabetic rats. The obtained data illustrated a gradual decrease of relative kidney weight, spleen weight, heart weight and liver weight with the increase in supplemented level. The statistical analysis showed a low significant correlation between treatments and organs ratio compared with positive control.This may be due to peels polyphones which increased the antioxidant capacity against the free radical in some organs. These results are in accordance with those of Oluremi $\boldsymbol{e t}$ al., (2008).

As shown In Table (3) Liver lipids profile of diabetic rats fed different levels of pomegranate peel showed a gradual decrease as the level of supplemented increased. A decrease of liver phospholipids and it varies among pomegranate peel feeding levels. The obtained data showed a gradual decrease in liver content of free fatty acids as a result of increased feeding pomegranate peel as supplemented in the diets. HDL-cholesterol of liver showed a gradual increase as the feeding supplemented pomegranate peel increased when compared with positive control. These results are in agreement with those reported by AbdelRahim et al.,(2013) and Neyrinck et al.,(2013) and Zhou Zhong; et al., (2012).

Dietary supplementation of pomegranate peel could be used up to have a favorable effect on improved CF digestibility coefficient, blood lipid profile, the semen quality and antioxidant status. Addition of pomegranate peel may have extra protective effect according to its contents of natural antioxidants by Fayed et al.,(2012).

These results suggest that WIFF could be a potential cholesterol-lowering ingredient in human diets or new formulations of fiber-rich functional foods. Chau et al., (2004).

Table (4) showed the effect of feeding different levels of pomegranate peel on liver functions of alloxan-induced diabetic rats .It was noted that GPT increased in G3 while decreased in G4,G5 when compared with positive control group. GOT increased in G3,G4 but decreased in G5 when compared with positive control group. Chau, et al., (2004) .who proofed that pomegranate peel are rich in polyphenols that exhibit antioxidant and anti-inflammatory capacities in vitro.

Table (5) reflected the effect of feeding different levels of pomegranate peel supplement on kidney functions of alloxan-induced diabetic rats. It showed increased of serum creatinine in all groups when compared with positive control group. Also urea gradually decreased with the increase of supplemented level when compared with the positive control group. These results are in agreement with those reported by Youssef (2013).

As shown in Table (6) blood glucose level was decreased gradually in diabetic rats, after two weeks from feeding on experimental supplements and the decrease was increased with the increase of supplemented level. Blood glucose was lower in all groups compared to positive control group. Group G5 had a lower values compared to others groups (15\% pomegranate peel). 
These results are in agreement with those reported by Youssef,etal (2013) and Najafzadeh $\boldsymbol{e t}$ al., (2010) that, pomegranate peel had marked protection, it brought down the level of blood sugar. Chau Chifai et al., (2003) suggested that, glucose lowering effects are most often associated with viscous fiber lies in the soluble dietary fiber content of peels.

In conclusion, supplemented with pomegranate peels reduced blood glucose level in diabetic rats, the reduction of blood glucose level increased with the increase of the supplemented peels.

Table (1): Effect of feeding on different levels of pomegranate peel on feed intake, food efficiency ratio (FER) and body weight gain (BWG) of diabetic rats.

\begin{tabular}{|c|c|c|c|c|c|c|}
\hline $\begin{array}{l}\text { Groups } \\
\text { Parameter }\end{array}$ & $\begin{array}{c}\text { G1 } \\
\text { (-ve ) }\end{array}$ & $\begin{array}{c}\text { G2 } \\
(+\mathbf{v e})\end{array}$ & $\begin{array}{c}\text { G3 } \\
(5 \%)\end{array}$ & $\begin{array}{c}\text { G4 } \\
(10 \%)\end{array}$ & $\begin{array}{c}\text { G5 } \\
(15 \%) \\
\end{array}$ & LSD \\
\hline $\begin{array}{c}\text { FI } \\
\text { Mean } \pm \text { SD }\end{array}$ & $\begin{array}{c}14.32^{b} \pm \\
0.56\end{array}$ & $\begin{array}{c}14.32^{b} \pm \\
0.91\end{array}$ & $\begin{array}{c}12.64^{\mathrm{c}} \pm \\
0.87\end{array}$ & $\begin{array}{c}14.44^{b} \pm \\
0.83\end{array}$ & $\begin{array}{c}15.36^{\mathrm{a}} \pm \\
0.86\end{array}$ & 0.910 \\
\hline $\begin{array}{c}\text { FER } \\
\text { Mean } \pm \text { SD }\end{array}$ & $\begin{array}{c}0.14^{\mathrm{c}} \pm 0 . \\
002\end{array}$ & $\begin{array}{c}0.11^{\mathrm{e}} \pm 0 . \\
003\end{array}$ & $\begin{array}{c}0.19^{\mathrm{a}} \pm 0 . \\
006\end{array}$ & $\begin{array}{c}0.17^{\mathrm{b}} \pm 0 \\
003\end{array}$ & $\begin{array}{c}0.12^{\mathrm{d}} \pm 0 . \\
004\end{array}$ & $\mathbf{0 . 0 0 6 9}$ \\
\hline $\begin{array}{l}\text { BWG (gld) } \\
\text { Mean } \pm \text { SD }\end{array}$ & $\begin{array}{c}42.27^{c} \pm \\
1.22\end{array}$ & $\begin{array}{c}92.70^{\mathrm{a}} \pm \\
1.32\end{array}$ & $\begin{array}{c}90.96^{b} \pm \\
1.3\end{array}$ & $\begin{array}{c}86.04^{\mathrm{c}} \pm \\
0.43\end{array}$ & $\begin{array}{c}66.45^{\mathrm{d}} \pm \\
0.44\end{array}$ & 1.872 \\
\hline
\end{tabular}

$*$ Mean \pm SD

Different letters on the numbers mean significant Differences at $\mathrm{P}<0.05$.

Feed intake (FI). Feed efficiency ratio (FER).Body weight gain (BWG).

Table (2): Effect of feeding on different levels of pomegranate peel on organs weight of diabetic rats (g).

\begin{tabular}{|c|c|c|c|c|c|c|}
\hline $\begin{array}{l}\text { Groups } \\
\text { Organs }\end{array}$ & $\begin{array}{c}\text { G1 } \\
\text { (-ve ) }\end{array}$ & $\begin{array}{c}\text { G2 } \\
(+\mathbf{v e})\end{array}$ & $\begin{array}{c}\text { G3 } \\
(\mathbf{5 \%})\end{array}$ & $\begin{array}{c}\text { G4 } \\
(10 \%)\end{array}$ & $\begin{array}{c}\text { G5 } \\
(15 \%)\end{array}$ & LSD \\
\hline Liver & $\begin{array}{l}5.92^{a b} \\
\pm 0.05\end{array}$ & $\begin{array}{l}7.33^{\mathrm{a}} \pm \\
0.22\end{array}$ & $\begin{array}{l}5.22^{\mathrm{bc}} \pm \\
0.08\end{array}$ & $\begin{array}{l}5.26^{c} \pm \\
0.12\end{array}$ & $\begin{array}{l}5.48^{b c} \pm \\
0.17\end{array}$ & 1.4326 \\
\hline Kidney & $\begin{array}{l}0.98^{b} \pm \\
0.01\end{array}$ & $\begin{array}{l}1.78^{\mathrm{a}} \pm \\
0.44\end{array}$ & $\begin{array}{l}\mathbf{0 . 9 8}^{\mathrm{b}} \pm \\
0.04\end{array}$ & $\begin{array}{l}0.92^{b} \pm \\
0.06\end{array}$ & $\begin{array}{l}1.05^{b} \pm \\
0.16\end{array}$ & 0.385 \\
\hline Spleen & $\begin{array}{l}1.43^{\mathrm{a}} \pm \\
0.18\end{array}$ & $\begin{array}{l}0.95^{b} \pm \\
0.10\end{array}$ & $\begin{array}{l}\mathbf{0 . 6 8}^{\mathbf{c}} \pm \\
0.03\end{array}$ & $\begin{array}{l}\mathbf{0 . 6 0}^{\mathbf{c}} \pm \\
0.05\end{array}$ & $\begin{array}{l}\mathbf{0 . 6 5}^{\mathbf{c}} \pm \\
0.03\end{array}$ & 0.175 \\
\hline Heart & $\begin{array}{l}0.75^{\mathrm{a}} \pm \\
0.19\end{array}$ & $\begin{array}{l}0.75^{\mathrm{a}} \pm \\
0.14\end{array}$ & $\begin{array}{l}0.68^{b} \pm \\
0.09\end{array}$ & $\begin{array}{l}0.74^{b} \pm \\
0.04\end{array}$ & $\begin{array}{l}0.67^{b} \pm \\
0.01\end{array}$ & 0.099 \\
\hline
\end{tabular}

*Mean \pm SD

Different letters on the numbers mean significant differences at $\mathrm{P}<0.05$. 
Table (3): Effect of feeding on different levels of pomegranate peel on liver lipid of diabetic rats $(\mathrm{mmoI} / \mathrm{L})$.

\begin{tabular}{|c|c|c|c|c|c|c|}
\hline $\begin{array}{l}\text { Groups } \\
\text { Lipid profile }\end{array}$ & $\begin{array}{c}\text { G1 } \\
(-\mathrm{-ve})\end{array}$ & $\begin{array}{c}\text { G2 } \\
(+\mathbf{v e})\end{array}$ & $\begin{array}{c}\mathbf{G 3} \\
(5 \%) \\
\end{array}$ & $\begin{array}{c}\mathbf{G 4} \\
(10 \%) \\
\end{array}$ & $\begin{array}{c}\text { G5 } \\
(15 \%) \\
\end{array}$ & LSD \\
\hline Total cholesterol & $\begin{array}{l}2.01^{c} \pm \\
0.93\end{array}$ & $\begin{array}{c}2.86^{\mathrm{a}} \pm \\
0.87\end{array}$ & $\begin{array}{c}2.66^{b} \pm \\
0.81\end{array}$ & $\begin{array}{c}2.43^{b} \pm \\
0.83\end{array}$ & $\begin{array}{c}2.31^{b} \pm \\
0.84\end{array}$ & 0.2001 \\
\hline Triglycerides & $\begin{array}{l}1.11^{b} \\
\pm 0.22\end{array}$ & $\begin{array}{c}1.42^{\mathrm{a}} \pm \\
0.18\end{array}$ & $\begin{array}{c}1.38^{\mathrm{a}} \pm \\
0.33\end{array}$ & $\begin{array}{c}1.21^{c} \pm \\
0.44\end{array}$ & $\begin{array}{c}1.15^{\mathrm{d}} \pm \\
0.32\end{array}$ & 0.046 \\
\hline Phospholipids & $\begin{array}{l}1.14^{\mathrm{c}} \\
\pm 0.13\end{array}$ & $\begin{array}{c}1.43^{\mathrm{a}} \pm \\
0.35\end{array}$ & $\begin{array}{c}1.35^{b} \pm \\
0.93\end{array}$ & $\begin{array}{c}1.27^{\mathrm{c}} \pm \\
0.81\end{array}$ & $\begin{array}{c}1.15^{\mathrm{d}} \pm \\
0.83\end{array}$ & 0.051 \\
\hline Free fatty acids & $\begin{array}{c}1.52^{c} \pm \\
0.66\end{array}$ & $\begin{array}{c}1.66^{\mathrm{a}} \pm \\
0.42\end{array}$ & $\begin{array}{c}1.64^{\mathrm{a}} \pm \\
0.19\end{array}$ & $\begin{array}{c}1.57^{\mathrm{b}} \pm \\
0.22\end{array}$ & $\begin{array}{c}1.47^{d} \pm \\
0.19\end{array}$ & 0.041 \\
\hline HDL-cholesterol & $\begin{array}{c}0.98^{\mathrm{a}} \pm \\
0.13\end{array}$ & $\begin{array}{c}0.91^{\mathrm{d}} \pm \\
0.04\end{array}$ & $\begin{array}{c}0.89^{\mathrm{e}} \pm \\
0.05\end{array}$ & $\begin{array}{c}0.93^{\mathrm{c}} \pm \\
0.09\end{array}$ & $\begin{array}{c}0.96^{b} \pm \\
0.06\end{array}$ & 0.0142 \\
\hline
\end{tabular}

**Mean \pm SD

Different letters on the numbers mean significant differences at $\mathrm{P}<0.05$.

Table (4): Effect of feeding on different levels of pomegranate peel on liver functions of diabetic rats.

\begin{tabular}{|c|c|c|c|c|c|c|}
\hline $\begin{array}{c}\text { Groups } \\
\text { Liver functions }\end{array}$ & $\begin{array}{c}\text { G1 } \\
\text { (-ve ) }\end{array}$ & $\begin{array}{c}\text { G2 } \\
(+\mathbf{v e})\end{array}$ & $\begin{array}{c}\text { G3 } \\
(5 \%)\end{array}$ & $\begin{array}{c}\mathbf{G 4} \\
(10 \%)\end{array}$ & $\begin{array}{c}\text { G5 } \\
(15 \%)\end{array}$ & LSD \\
\hline GPT(ALT) & $\begin{array}{c}27.70^{c} \pm \\
1.2\end{array}$ & $\begin{array}{c}37.75^{b} \pm \\
1.18\end{array}$ & $\begin{array}{c}55.60^{\mathrm{a}} \pm \\
1.4\end{array}$ & $\begin{array}{c}21.20^{\mathrm{e}} \pm \\
1.1\end{array}$ & $\begin{array}{c}25.10^{d} \pm \\
0.27\end{array}$ & 2.0002 \\
\hline GOT(AST) & $\begin{array}{c}28.00^{\mathrm{e}} \pm \\
1.5\end{array}$ & $\begin{array}{c}69.63^{c} \pm \\
1.18\end{array}$ & $\begin{array}{r}112.60^{\mathrm{a}} \\
\pm 1.03\end{array}$ & $\begin{array}{c}79.00^{b} \pm \\
1.13\end{array}$ & $\begin{array}{c}62.33^{d} \pm \\
1.16\end{array}$ & 2.02 \\
\hline
\end{tabular}

*Mean \pm SD

Different letters on the numbers mean significant differences at $\mathrm{P}<0.05$.

Table (5): Effect of feeding on different levels of pomegranate peel on kidney Functions of diabetic rats.

\begin{tabular}{|c|c|c|c|c|c|c|}
\hline $\begin{array}{l}\text { Groups } \\
\text { Kidney } \\
\text { functions }\end{array}$ & $\begin{array}{c}\text { G1 } \\
\text { (-ve ) }\end{array}$ & $\begin{array}{c}\text { G2 } \\
(+\mathbf{e})\end{array}$ & $\begin{array}{c}\mathbf{G 3} \\
(5 \%)\end{array}$ & $\begin{array}{c}\mathbf{G 4} \\
(10 \%)\end{array}$ & $\begin{array}{c}\text { G5 } \\
(15 \%)\end{array}$ & LSD \\
\hline $\begin{array}{c}\text { Creatinine } \\
\text { (mg/100ml) }\end{array}$ & $\begin{array}{l}0.57^{\text {ab }} \\
\pm 0.03\end{array}$ & $\begin{array}{c}0.46^{b} \pm 0 . \\
01\end{array}$ & $\begin{array}{c}0.69^{\mathrm{a}} \pm \\
0.12\end{array}$ & $\begin{array}{c}0.56^{\mathbf{a b}} \pm 0 \\
.07\end{array}$ & $\begin{array}{c}0.48^{\mathrm{b}} \pm 0 \\
08\end{array}$ & 0.1329 \\
\hline $\begin{array}{c}\text { Urea } \\
(\mathrm{mg} / \mathbf{1 0 0 m l})\end{array}$ & $\begin{array}{c}51.17^{\mathrm{d}} \pm \\
1.1\end{array}$ & $\begin{array}{c}84.25^{\mathrm{a}} \pm \\
0.85\end{array}$ & $\begin{array}{c}67.60^{\mathrm{c}} \pm \\
0.77\end{array}$ & $\begin{array}{l}\mathbf{7 1 . 8 0}^{\mathrm{b}} \\
\pm 0.87\end{array}$ & $\begin{array}{c}50.50^{\mathrm{d}} \pm \\
0.11\end{array}$ & 1.476 \\
\hline
\end{tabular}

*Mean \pm SD

Different letters on the numbers mean significant differences at

$\mathrm{P}<0.05$. 
Table (6): Effect of feeding on different levels of pomegranate peel on glucose level of diabetic rats $(\mathrm{mg} / \mathrm{dl})$.

\begin{tabular}{|c|c|c|c|c|c|c|}
\hline $\begin{array}{l}\text { Groups } \\
\text { Feeding } \\
\text { period }\end{array}$ & $\begin{array}{c}\text { G1 } \\
(-v e)\end{array}$ & $\begin{array}{c}\text { G2 } \\
(+\mathrm{ve})\end{array}$ & $\begin{array}{c}\text { G3 } \\
(5 \%)\end{array}$ & $\begin{array}{c}\text { G4 } \\
(10 \%)\end{array}$ & $\begin{array}{c}\text { G5 } \\
(15 \%)\end{array}$ & LSD \\
\hline $\begin{array}{c}1 \\
\text { Week }\end{array}$ & $\begin{array}{c}98.50^{\mathrm{e}} \pm \\
1.12\end{array}$ & $\begin{array}{c}388.20^{\mathrm{a}} \\
\pm 2.34 \\
\end{array}$ & $\begin{array}{c}372.20^{b} \\
\pm 1.99 \\
\end{array}$ & $\begin{array}{c}352.20^{c} \pm \\
2.42\end{array}$ & $\begin{array}{r}276.40^{d} \\
\pm 1.18 \\
\end{array}$ & 3.489 \\
\hline $\begin{array}{c}2 \\
\text { Week }\end{array}$ & $\begin{array}{c}92.20^{\mathrm{e}} \pm \\
1.13\end{array}$ & $\begin{array}{c}361.40^{\mathrm{a}} \\
\pm 2.33\end{array}$ & $\begin{array}{r}355.30^{b} \\
\pm 1.01\end{array}$ & $\begin{array}{c}334.20^{c} \pm \\
1.13\end{array}$ & $\begin{array}{r}255.30^{d} \\
\pm 1.19\end{array}$ & 2.626 \\
\hline $\begin{array}{c}3 \\
\text { Week } \\
\end{array}$ & $\begin{array}{c}90.70^{\mathrm{e}} \pm \\
1.11\end{array}$ & $\begin{array}{c}327.20^{\mathrm{a}} \\
\pm 2.05\end{array}$ & $\begin{array}{r}318.20^{b} \\
\pm 1.56 \\
\end{array}$ & $\begin{array}{c}288.50^{c} \pm \\
1.98\end{array}$ & $\begin{array}{r}238.60^{d} \\
\pm 1.73 \\
\end{array}$ & 3.048 \\
\hline $\begin{array}{c}4 \\
\text { Week }\end{array}$ & $\begin{array}{c}89.80^{\mathrm{e}} \pm \\
0.98\end{array}$ & $\begin{array}{r}288.30^{\mathrm{a}} \\
\pm 1.18\end{array}$ & $\begin{array}{r}276.20^{b} \\
\pm 1.33\end{array}$ & $\begin{array}{c}237.50^{c} \pm \\
1.05\end{array}$ & $\begin{array}{r}200.61^{d} \\
\pm 1.33\end{array}$ & 2.046 \\
\hline
\end{tabular}

* Mean \pm SD

Different letters on the numbers mean significant differences at $\mathrm{P}<0.05$.

Microscopically, pancreas of rat from negative control (G1) showed normal islets of Langerhans (Photo 1). While, pancreas of rat from positive control (G2) showed atrophy and vacuolation of B cell of islets of langerhans. Meanwhile, Pancreas of rat from all other diabetic groups showed no histopathological changes.

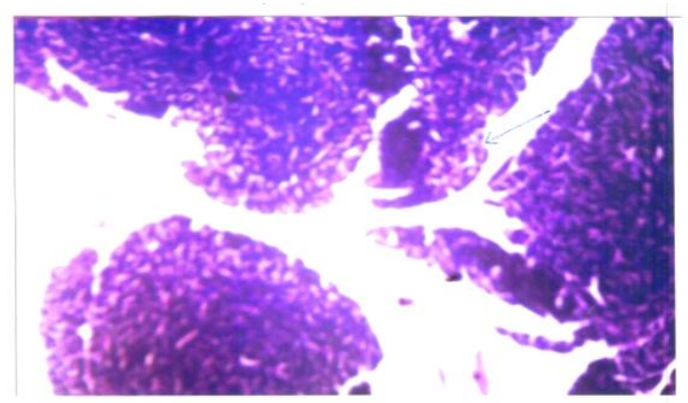

serous acini and normal islats of langer han's cells were present. (H \& E. $\times 100)$.

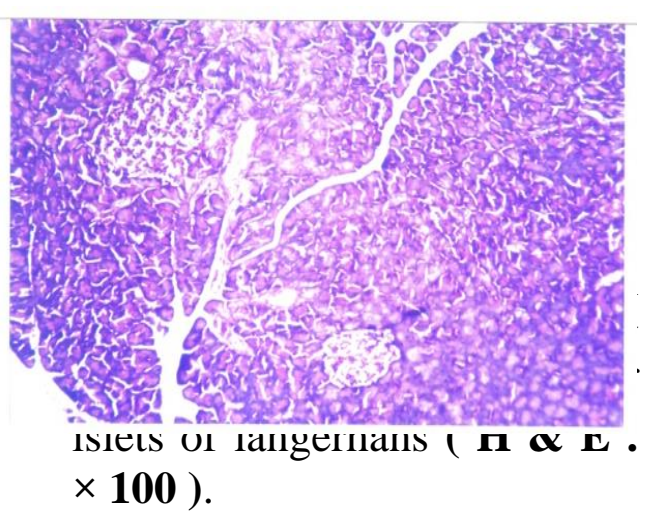

$\times 100)$. 


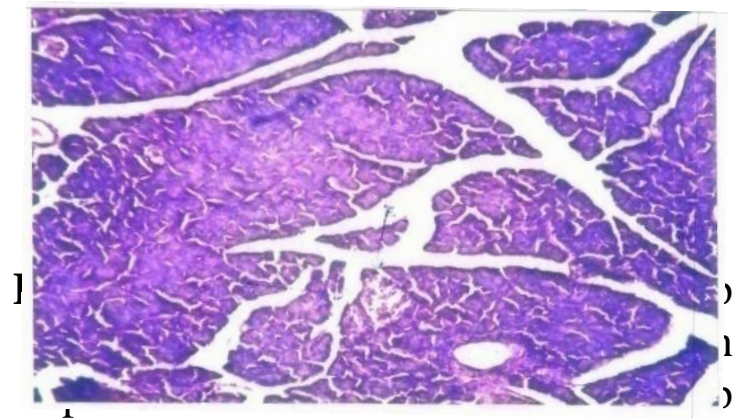

serous acini and normal islats of langer han's cells were present .( $\mathrm{H}$ \& E . × 100$)$.

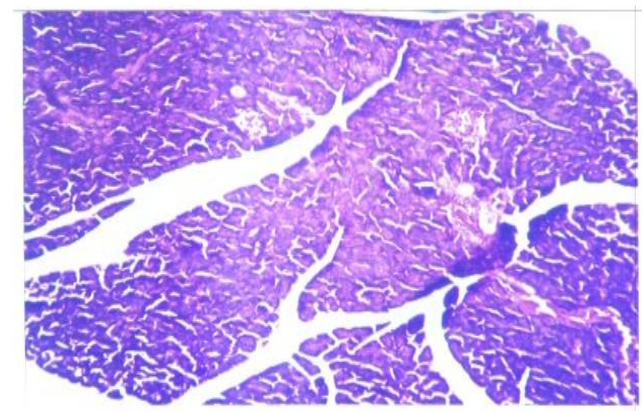

architecture. normal pancreatic serous acini and normal islats of langer han's cells were present. (H \& E. $\times 100)$.

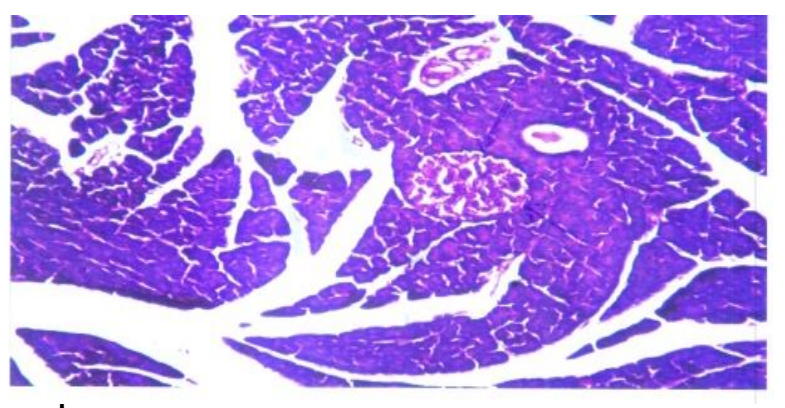

pancreatic serous acini and normal islats of langer han's cells were present. (H \& E . × 100). 


\section{References}

Abdel-Rahim, E. A.; El-Beltagi, H. S. And Romela, R. M.(2013) White bean seeds and Pomegranate peel and fruit seeds as hypercholesterolemic and hypolipidemic agents in albino rats. Grasas y Aceites (Sevilla); 2013. 64(1):50-58.

AIN (1977) American Institute of Nutrition (AIN), Committee on Standard Nutritional Studies. J. Nutr. 107:1340-1348.

AIN (1993). American Institute of Nutrition (AIN), Purified diet for Laboratory Rodent. J. Nutr. 123:1939-1951.

Bligh, E. G. and Dyer, W. J. (1959) A rapid method of total lipid extraction and purification. Con. J. of Biochem. And Physiol. 37: 911.

Bohmer, H. B. U. M. (1971) Micro-determination of creatinine. Clin. Chem. Acta, 32: 81 - 85 .

Carle`ton, H .(1979) : In "Histological Techniques" ,4th Edition ,London, Oxford University Press. New York, USA.

Chau ChiFai; Huang, Y. and Lee, M.(2003) In vitro hypoglycemic effects of different insoluble fiber-rich fractions prepared from the peel of Citrus sinensis L. cv. Liucheng. Journal of Agricultural and Food Chemistry. 51(22):6623-6626.

Chau, C. F.; Huang, Y. L.; and Lin, C. Y.(2004) Investigation of the cholesterol-lowering action of insoluble fibre derived from the peel of Citrus sinensis L. cv. Liucheng. Food Chemistry. 87(3):361-366.

Desia, A. and Bhide, M. (1985) Hypoglycemic effect of hanitionia suaveolens. Indian. J. Med. 81: 86-91.

Falholt, K.; Lund, B. and Falholt, W. (1973). ) Determination of free fatty acids. Clin.Chem. Acta, 49,105.

Fayed, A. M.; Azoz, A. A.; Zedan, A. H.; and Basyony, M.(2012) Effect of pomegranate peel as antioxidant supplementation on digestibility, blood biochemical and rabbit semen quality.Egyptian Journal of Nutrition and Feeds; 15(2):323-334.

Kaplan, A. (1984) Determination of blood glucose. Cline. chem. The C.V. Mosby. Co. St Louis Toronto. Princeton, pp. 1032 - 1036.

Lawrence, J.M.;Contreras. R.; Chen . W. and Sacks.D.A.(2005). Trends in the prevalence of population of pregnant women ,Diabetes Care 31(5)899- 904

Najafzadeh, H.; Aghel, N.; Hemmati, A. A. and Oulapour, S.,(2010). Effect of hydro alcoholic extract of peel of Punica granatum on experimental diabetes mellitus by streptozotocin in rats. Pharmaceutical Sciences; 2010. 16(4):239-248.

National Diabetes Data Group (NDDG) (1994). Classification and diagnosis of diabetes mellitus and other categories of glucose intolerance. Diabetes, 28:1039-1057. 
Neyrinck, A. M.; Hee, V. F. van; Bindels, L. B.; Backer, F. de; Cani, P. D. and Delzenne, N.M.(2013). Polyphenol-rich extract of pomegranate peel alleviates tissue inflammation and hypercholesterolaemia in highfat diet-induced obese mice: potential implication of the gut microbiota. British Journal of Nutrition;: 109(5):802-809.

Oluremi, O. I. A.; Mou, P. M. and Adenkola, A. Y. (2008): Effect of fermentation of sweet orange (Citrus sinensis) fruit peel on its maize replacement value in broiler diet.Livestock Research for Rural Development. 20(2):20020. 19 ref.

Patton, C. and Crouch, S. R. (1977). Determination of urea. Anal. Chem. 149:464-469.

Prakash, C. V. S. and Prakash, I. (2011). Preexisting diabetes and gestational diabetes mellitus among a racially / ethnically diverse. Int. J. Res. Chem. Environ, 1,1-8.

Reitman, S. and Frankel, S. (1957). A color metric method for the determination of serum glutamic oxaloacetic and glutamic pyruvic transaminases. Am. J. Clin. Path, 28: $56-63$.

Snedecor, G. W. and Cochran, W. G. (1972). Statistical Methods $6^{\text {th }}$ Ed. The Iowa State University Press. Ames. IA.

Trinder, P. (1969). Determination of blood glucose. Ann.Clin. Biochem. 6: 24 33.

Youssef, M. K. E.; Youssef, H. M. K. E.; and Mousa, R. M. A,(2013). Evaluation of antihyperglycaemic activity of citrus peels powders fortified biscuits in Albino induced diabetic rats. Food and Public Health. 3(3):161-167.

Zhou Zhong; Jiao Yi; Lian Zheng; Han ChunChen; Yang WenHao; Fu WenNing; Li DanLu; Lei Chao; Li JunHong; and Guan YaQun,(2012). The influence pomegranate peels extract on blood glucose and blood lipids of rats. Journal of Xinjiang Medical University; .35(5):570-574.

Zolliner and Eberhagal. (1965). Determination of phospholipids. Ann.Clin. Biochem. 6: 538 - 544 . 